\title{
IPTEKS PENGGUNAAN E-BILLING WAJIB PAJAK PADA PT BANK SULUTGO
}

\author{
Cindy Helena Wowor $^{1}$, Jannifer Vilisia Kumendong ${ }^{2}$, Grace B. Nangoi ${ }^{3}$ \\ ${ }^{1,2,3}$ Jurusan Akuntansi, Fakultas Ekonomi dan Bisnis, Universitas Sam Ratulangi, Kampus Unsrat, Sulawesi \\ Utara, 95115, Indonesia \\ E-mail: cindyhelena109@gmail.com
}

\begin{abstract}
In this increasingly developing era, a more active role is needed from taxpayers to calculate, deposit and report independently taxpayer tax obligations. Moreover, the largest regional bank company in the North Sulawesi and Gorontalo regions, namely PT Bank SulutGo, must follow the developments of the existing era where all have been based on technology. PT Bank SulutGo has been appointed as a perception bank on December 11, 2014 and uses an ebilling system launched by the Directorate General of Taxes so that tax payments are made easier.
\end{abstract}

Keywords : e-billing PT Bank SulutGo the largest regional bank

\section{PENDAHULUAN}

Bidang perpajakan adalah bagian dari bidang keuangan. Setiap perusahaan mempunyai kewajiban yang besar untuk membayar pajak kepada negara karena pajak adalah pendapatan negara yang diperuntukkan sebagai pembiayaan pembangunan negara, pajak juga dapat menggambarkan perekonomian suatu negara. E-billing merupakan suatu sistem pembayaran pajak secara elekronik, sehingga Wajib Pajak diberikan kepercayaan untuk membayar pajaknya secara mandiri atau dinamakan self assessment system melalui kode billing yang adalah kode identifikasi yang digunakan dalam pembayaran termasuk didalamnya pembayaran pajak oleh Wajib Pajak yang didapatkan dari sistem billing.

PT Bank SulutGo sudah menggunakan pembayaran pajak yang lebih mudah dan modern yaitu secara elektronik melalui Modul Penerimaan Negara Generasi II (MPN G2). MPN G2 merupakan bentuk penyempurnaan dari Modul Penerimaan Negara Generasi I (MPN G1) dimana dahulu masih menggunakan cara manual yang sekarang telah dirubah menjadi sistem elektronik yaitu dalam bentuk billing. Dengan adanya MPN G2 informasi penerimaan negara disajikan dengan sebenar-benarnya pada saat itu juga atau dengan istilah real time.

\section{TINJAUAN PUSTAKA}

Akuntansi Perpajakan. Agoes dan Estralita (2013:10) memberi pengertian akuntasi pajak adalah menetapkan besarnya pajak terutang berdasarkan laporan keuangan yang disusun oleh perusahaan. Menurut Wikipedia pengertian akuntansi pajak adalah akuntansi yang diterapkan dengan tujuan untuk menetapkan besarnya pajak terutang. Secara umum akuntansi perpajakan adalah suatu seni mencatat, menggolongkan, mengikhtisarkan dan menafsirkan transaksi-tranksaksi finansial yang dilaksanaan oleh perusahaan dengan tujuan menentukan jumlah penghasilan kena pajak yang diperoleh atau diterima dalam suatu tahun pajak guna sebagai dasar penetapan beban atau pajak penghasilan yang terutang oleh perusahaan sebagai wajib pajak.

Pengertian Pajak. Pengertian pajak berdasarkan UU KUP Nomor 28 Tahun 2007 Pasal 1 ayat 1 adalah kontribusi wajib kepada negara yang terutang oleh orang pribadi atau badan yang bersifat memaksa berdasarkan Undang-Undang, dengan tidak mendapatkan 
imbalan secara langsung dan digunakan untuk keperluan negara bagi sebesar-besarnya kemakmuran rakyat.

Fungsi Pajak. Terdapat 2 fungsi pajak yaitu: (1) Fungsi Anggaran/Budgetair adalah pajak sebagai sumber dana terbesar bagi pemerintah untuk pembiayaan pengeluaran pemerintah yang dilakukan untuk pembangunan negara; (2) Fungsi Mengatur/Regulerend adalah pajak memiliki fungsi sebagai sarana dalam melaksanakan maupun mengatur kebijaksanaan pemerintah dalam bidang sosial dan yang terutama bidang ekonomi.

Wajib Pajak. Menurut Undang-Undang nomor 28 Tahun 2007 tentang Ketentuan Umum dan Tata Cara Perpajakan Pasal 1 Ayat 2 disebutkan pengertian Wajib Pajak adalah orang pribadi atau badan, meliputi membayar pajak, pemotong pajak dan pemungut pajak yang mempunyai hak dan kewajiban perpajakan sesuai dengan ketentuan perundangundangan perpajakan. Wajib Pajak terdiri atas tiga jenis yaitu, Wajib Pajak Orang Pribadi, Wajib Pajak Badan, dan Wajib Pajak Bendahara.

Kepatuhan Wajib Pajak. Wajib Pajak diharuskan untuk mematuhi segala kewajiban sebagai Wajib Pajak diantaranya yaitu menyetorkan pajaknya dan melaksanakan hak perpajakan Wajib Pajak.

Pajak Daerah. Pajak daerah merupakan kewajiban Wajib Pajak Badan maupun Wajib Pajak Orang Pribadi untuk berkontribusi kepada daerah berdasarkan undang-undang dengan sifat memaksa, yang selanjutnya akan digunakan untuk keperluan maupun pembangunan daerah tersebut.

Pengertian e-Billing. E-billing merupakan suatu sistem pembayaran pajak yang lebih modern yaitu secara elekronik, sehingga Wajib Pajak diberikan kepercayaan untuk membayar pajaknya secara mandiri atau dengan kata lain self assessment system melalui kode billing. Kode billing merupakan kode identifikasi khusus yang digunakan dalam pembayaran termasuk didalamnya pembayaran pajak oleh Wajib Pajak yang didapatkan dari sistem billing.

\section{METODE DAN TEKNIK PENERAPAN IPTEKS}

\subsection{Metode Penerapan Ipteks}

Metode IPTEKS yang digunakan adalah metode secara langsung untuk mengetahui apakah e-Billing berpengaruh terhadap kepatuhan PT Bank SulutGo dalam membayar pajak kepada Negara, juga untuk mengetahui bagaimana penerapan e-Billing di PT Bank SulutGo.

\subsection{Teknik Penerapan Ipteks}

Metode Langsung, metode langsung dalam e-Billing yaitu transaksi pembayaran pajak yang dilakukan secara mandiri dengan mengambil kode Billing di https://www.sse2.pajak.go.id.

\section{PEMBAHASAN}

\subsection{Gambaran Objek Penerapan IPTEKS}

PT Bank SulutGo didirikan pada tanggal 17 Maret 1961 dengan nama Bank Pembangunan Daerah Sulawesi Utara Tengah, kemudian pada tanggal 19 April 1999 berganti nama menjadi PT Bank Sulut dan terakhir pada tanggal 23 September 2015 berubah nama menjadi PT Bank Pembangunan Daerah Sulawesi Utara Gorontalo atau yang lebih dikenal PT Bank SulutGo. PT Bank SulutGo dipimpin oleh 5 Direksi yaitu Direktur Utama, Direktur Kepatuhan, Direktur Pemasaran, Direktur Umum, dan Direktur Operasional.

\subsection{Pembahasan}

Aktivitas operasional. Aktivitas operasional merupakan aktivitas utama yang menghasilkan pendapatan bagi perusahaan. Pendapatan yang dihasilkan berasal dari barang atau jasa. Penerapan e-Billing. Sebelum diterapkannya e-Billing pada tanggal 1 Januari 2016 transaksi pajak dilakukan dengan cara menggunakan lembaran SSP atau Surat Setoran Pajak 
yaitu pembayaran pajak yang dilakukan secara manual. Pada saat akan menggunakan eBilling Wajib Pajak diharuskan membuat ID Billing terlebih dahulu untuk mendapatkan kode Billing. Dengan adanya ID Billing Wajib Pajak dipermudah dalam memenuhi kewajibannya sebagai Wajib Pajak yaitu membayarkan pajaknya kapan saja dan dimana saja melalui Automatic Teller Machine (ATM) atau melalui internet banking tanpa harus mengantri di tempat tertentu. Wajib Pajak hanya diharuskan membawa kode Billing Wajib Pajak. Dalam pembayaran pajak secara e-Billing dapat mengurangi kesalahan dalam pencatatan transaksi. Segala transaksi dalam e-Billing dicatat dengan sebenar-benarnya atau pada saat transaksi terjadi dan langsung tercatat di Direktorat Jenderal Pajak. Beberapa langkah-langkah dalam membuat ID Billing yaitu : (1) masuk ke halaman web https://www.sse.pajak.go.id dan selajutnya memilih daftar baru; (2) pada saat memilih daftar baru wajib pajak akan dimintai untuk mengisi data diri masing-masing diantaranya nama wajib pajak, npwp dan email yang aktif; (3) setelah daftar pihak https://www.sse.pajak.go.id akan mengirimkan aktivasi id billing ke email yang telah diregistrasikan; dan (4) jika sudah berhasil, masuk lagi ke halaman pertama https://www.sse.pajak.go.id dan setelah itu masukkan NPWP dan password yang telah diregistrasi. Dapat dikatakan bahwa e-Billing sangat berpengaruh positif dan signifikan terhadap PT Bank SulutGo karena setiap transaksi pembayaran pajak PT Bank SulutGo maupun nasabah PT Bank SulutGo sudah menggunakan e-Billing.

\section{KESIMPULAN DAN SARAN}

\subsection{Kesimpulan}

Setiap Wajib Pajak diharuskan memenuhi kewajiban terhadap Negara diantaranya membayar pajak. Pajak memiliki sifat memaksa. Terdapat beberapa cara Wajib Pajak dalam membayar pajak, diantaranya e-Billing. e-Billing adalah cara pembayaran pajak secara elektronik yang dikeluarkan oleh Direktoran Jenderal Pajak. Dengan adanya e-Billing Wajib Pajak diberikan kesempatan untuk membayarkan dan melaporkan pajak secara mandiri. Dengan adanya e-Billing Wajib Pajak dipermudah membayar pajak kapan saja dan dimana saja karena transaksi yang dilakukan akan langsung terekam di Direktorat Jenderal Pajak.

\subsection{Saran}

Saran yang dapat diberikan dari hasil penelitian ini terhadap PT Bank SulutGo yaitu sebaiknya PT Bank SulutGo terus meningkatkan kualitas internet dan selalu menyediakan listrik pengganti atau dalam bentuk genset karena jika internet atau listrik bermasalah maka sistem pun akan bermasalah karena sistem tergantung pada jaringan internet dan arus listrik.

\section{DAFTAR PUSTAKA}

Agoes, Estralita. 2013. Akuntansi Perpajakan. Edisi 3. Jakarta: Salemba Empat.

Direktorat Jenderal Pajak, UU KUP Nomor 28 Tahun 2007 tentang Ketentuan Umum dan Tata Cara Perpajakan.

Website Resmi Perusahaan PT Bank SulutGo https://www.banksulutgo.co.id. Diakses 13 Desember 2008.

Finny Tania Rachdianti, Endang Siti Astuti, dan Heru Susilo. 2016. Pengaruh Penggunaan E-Tax Terhadap Kepatuhan Wajib Pajak (Studi Pada Wajib Pajak Terdaftar di Dinas Pendapatan Daerah Kota Malang). Jurnal Perpajakan (JEJAK) Vol. 11 No. 1. Malang.

Kode Billing dan Modul Penerimaan Negara Generasi II (MPN G2). https://www.djpbn.kemenkeu.go.id. Diakses pada 03 Februari 2016.

Mardiasmo. 2018. PERPAJAKAN. Edisi Terbaru 2018. Yogyakarta: Andi. 
Mentari, Dara Ayu. 2016. Analisis Pengaruh Penerapan Metode e-Billing dan Manual Wajib Pajak Badan Terhadap Penerimaan Pajak Pada Kantor Pelayanan Pajak Penanaman Modal Asing Enam, Jakarta. Skripsi. Fakultas Ekonomi dan Bisnis Universitas Lampung: Lampung.

S, Dahlan Hadyan. 2017. Pengaruh Penerapan Sistem E-Billing Terhadap Kepatuhan Wajib Pajak Di KPP Pratama Kabupaten Pandeglang. Jurnal KAPemda-Kajian Administrasi dan Pemerintahan Daerah. Kabupaten Pandeglang Vol. 11 No. 6. Pandeglang.

Soemitro, Rochmat. 2007. Dasar-Dasar Hukum Pajak dan Pajak Pendapatan. Bandung: Eresco.

T, Gilarso. 2004. Pengantar Ilmu Ekonomi Makro. Yogyakarta: Kanisius.

Wahyu Handayani. 2017. Pengaruh Penerapan Billing System Terhadap Kepatuhan Wajib Pajak Dengan Moderasi Pemahaman Perpajakan (Studi Pada KPP Pratama Surabaya Karangpilang). Jurnal Ekonomi Akuntansi Vol. 3 No. 4. Surabaya.

Waluyo. 2011. Akuntansi Perpajakan. Jakarta: Salemba Empat. 